\title{
The realization of speech acts of refusals of an invitation among Brazilian friends
}

\author{
A realização de atos de fala de recusa a um convite \\ entre amigos brasileiros
}

\author{
Denise M. Osborne \\ University of Arizona - EUA
}

\section{Resumo}

Este estudo investiga os atos de fala de recusa na fala espontânea de quatro falantes do português brasileiro (PB). Seguindo a análise racional de Beebe et al. (1990), o conteúdo e a ordem das estratégias pragmáticas foram analisadas. Não obstante as similaridades encontradas entre as fórmulas semânticas de Beebe et al. e o presente estudo (e.g., Alternativas e Promessas), na tentativa de preservação das faces, os participantes usaram outras fórmulas (e.g., Digressão e Recusas Incompletas). A falta de marcas convencionais de polidez (e.g., obrigado, me desculpe), a Troca de Perspectiva (do eu para o Impessoal), e a Continuação Pós-encerramento foram aspectos distintos entre os participantes. A ordem das fórmulas semânticas revelaram ser um processo elaborado (e.g., Softeners $\rightarrow$ Recusa Direta $\rightarrow$ Justificativa $\rightarrow$ Reparo Positivo $\rightarrow$ Promessa).

Palavras-chave

Atos de fala, Recusa, Fala espontânea, Aspectos pragmáticos. 


\begin{abstract}
This study investigates the speech acts of refusal in the natural speech of four native speakers of Brazilian Portuguese (BP). Following the rationale in Beebe et al. (1990)'s study, the content and order of the pragmatic strategies were analyzed. Notwithstanding the similarities found between semantic formulas in Beebe et al.'s study and the present one (e.g., Alternatives and Promises), in trying to save face, BP speakers used other formulas (e.g., Digression and Incomplete Refusals). The lack of conventional politeness markers (e.g., thank you, I'm sorry), the Shifting Perspective (from I to the Impersonal), and the Post-closure Continuance were distinctive features observed among BP speakers. The participants showed that the order of semantic formulas can be an elaborate process (e.g., Softeners $\rightarrow$ Direct Refusal $\rightarrow$ Justification $\rightarrow$ Positive Remark $\rightarrow$ Promise).
\end{abstract}

\title{
Keywords
}

Speech acts, Refusal, Natural speech, Pragmatic features. 


\section{Introduction}

he study of speech acts has helped us better understand the interactional styles and differences in speech act behavior within and across cultures.

Some scholars have argued that speech acts are regulated by universal principles of cooperation and politeness (BROWN; LEVISON, 1978). Crosscultural studies have demonstrated, however, that interaction among members of different cultures may result in breakdowns and communication problems, since different cultures may have different expectations and styles (GUMPERZ, 1978). The study of the speech acts of refusals is especially interesting because it may require extensive planning on the part of the refuser. In addition, the number of possible responses is broader than the initiating act of the offer (GASS; HOUCK, 1999). Thus, refusals may turn out to be very complex forms of interaction.

The discussion to focus on refusals of invitation is based on the fact that this is a frequent speech act in the everyday life of Brazilians. In addition, refusals are considered face-threatening (BROWN; LEVINSON, 1978), since the act threatens the listener's positive face. Therefore, it is interesting to analyze what kinds of strategies and semantic formulas are used by Brazilian Portuguese (BP) speakers, as well as other possible aspects of the interaction that might occur during the refusing of an invitation.

This paper begins with a brief literature review on the study of the speech acts of refusals and the study of pragmatics in BP. It is followed by the methodology employed in the study, and the data analysis section. The paper concludes with the limitations of the study and some suggestions for future investigations. 


\section{Literature Review}

\subsection{Speech Acts of Refusals}

Studies of refusals have been conducted focusing on either cross-cultural interactions or interlanguage pragmatics (e.g., BARRON, 2003; FELIXBRASDEFER, 2004; BEEBE et al., 1990). Such studies have revealed that the offer-refusal speech act can contain characteristics that are culture-specific. The study of refusals is, therefore, not only relevant in cross-cultural studies, but also in the area of second language acquisition and instruction, since pedagogical intervention can help non-native learners develop their pragmatic competence. Instruction in pragmatic competence helps second language (L2) learners become aware of pragmatic knowledge that can be considered more universal (e.g., conversational organization with turn-taking), and of pragmatic aspects that can be successfully transferred from learners' first language (L1) to L2. It can also provide learners with new information which helps students to avoid pragmatic failure (ROSE; KASPAR, 2001).

A refusal is a type of speech act that is a response to another speech act (e.g., an invitation). Refusals can require planning from the refuser, can have broader possibilities of responses than other speech acts, and can be facethreatening (GASS; HOUCK, 1999). Consequently, cross-cultural differences might occur since "a certain amount of cultural-specific knowledge and ability on the part of the refuser" (p. 3) is required. Moreover, Beebe et al. (1990) argue that refusals can involve long sequences of negotiation and that form and content vary depending on the type of eliciting speech act (e.g., if it is an invitation or a request).

The most influential study of refusals was probably the one conducted by Beebe et al. (1990). In their study, Japanese learners of English and native speakers of English and Japanese filled out a Discourse Completion Test (DCT). The results showed that negative transfer occurred in the interlanguage pragmatics of Japanese speakers of English in three areas: the order, the frequency, and the content of semantic formulas. Japanese tend to give different responses to high- and low-status interlocutors, for example. When they are higher in status than the person who invites them, they generally omit expressions of apology or regret.

Other studies have focused on the acquisition of speech acts of refusals in other languages, such as Spanish and German. Astudy investigating interlanguage refusals by American learners of Spanish (FÉLIX-BRASDEFER, 2004) shows 
that length of residence is an influential factor in learners' organization of politeness strategies and in learners' ability to negotiate refusals. Learners who had spent more time in the target community used more lexical and syntactic mitigation and showed more frequent attempts at negotiation, which is closer to what native speakers of Spanish would do.

The influence of a year abroad in the acquisition of the pragmatics of request, offers, and refusals in German was investigated by Barron (2003). The participants in her study were Irish college students who spent a year in Germany. The results showed that a year of study in the target language community helped improve the interlanguage pragmatics to become more target-like.

Refusals can also be perceived differently by native and non-native speakers. In a study involving learners of Spanish, Félix-Brasdefer (2008) observed that Americans and Spanish speakers perceive insistence differently. For Spanish speakers, insistence is expected; whereas Americans tend to consider insistence as imposing and rude.

Studies on speech acts of refusals have shown that in order to successfully communicate with each other, speakers have to demonstrate that they possess not only grammatical knowledge, but also pragmatic competence. The studies conducted in pragmatics in Portuguese have also contributed to the understanding of language in social interaction.

\subsection{The study of pragmatics in Portuguese}

The study and analysis of oral speech in Brazil took its first meaningful step in a conference on linguistics in 1969 in São Paulo when the project NURC [Projeto de Estudo da Norma Urbana Culta - Project of the Study of the Educated Urban Norm] (Projeto NURC/SP, 2009) was launched. Participants in this project collected oral data from educated speakers (those who have college degrees) during the 1970's in five big cities in Brazil. An impressive amount of hours (more than 1,600 hours) was recorded and, since then, the data have been analyzed. This research on the oral production of educated Brazilians revealed, among other things, that the educated norm is different from the standard norm; many educated speakers of Brazilian Portuguese (BP) do not employ certain norms of the standard Portuguese. The use of personal pronouns as indirect objects, for example, occurs frequently among educated norm speakers (e.g., Eu conheço ele "I know he" instead of the standard norm Eu o conheço "I know him".) 
Although this project has been an important step in the investigation of oral language, the study of the pragmatics of Portuguese is considered a recent endeavor (KORSKO, 2004). Koike (1992), who did a comprehensive study of the pragmatics of politeness of $\mathrm{BP}$, cites some interesting aspects of BP pragmatics; among them, the use of diminutives. According to Koike, diminutives "can serve to lessen the force of a request by belittling the object of request or by making the request seem inconsequential” (p. 56). BP speakers might say, for example, Me dá um copinho de água. ('Give me a little glass of water.').

It is interesting to notice that, in this example given above by Koike, the speaker does not use the word por favor ('please'), which is a conventional lexical marker of politeness in Portuguese. The limited use of por favor by BP was observed by Naiditch (2006). According to Naiditch, the lack of this lexical marker of politeness does not express rudeness and it does not threaten the speakers' positive face, that is, it is not perceived by the hearer as lack of politeness. Naiditch also states that BP speakers may use "other resources to express politeness in discourse, such as prosodic and paralinguistic features” (p. 122).

The study of BP pragmatics has revealed some other idiosyncratic pragmatic features. In BP, there are three ways in which speakers can express negation. 'I didn't turn off the TV', for example, can occur in three forms: Eu não desliguei a TV, Eunão desliguei a TVnão, and Eu desliguei a TVnão. According to Schwenter (2005), "the discourse status (old/new) of the preposition being denied" (p. 1427) is the pragmatic difference that determines when each negation is used by the speakers. Questions such as 'Did you turn off the TV?', trigger the double negation in BP because it has the status of discourse old ('turn off the TV' was mentioned in the question). However, if the speaker initiates the topic (discourse new), double negation is not possible (e.g., the speaker suddenly remembers that he or she did not turn off the TV.). Schwenter's analysis is especially revealing, since prior studies on negation have explained the use of the three forms in terms of emphasis and reinforcement.

The speech act of complaining among European Portuguese was investigated by Korsko (2004). In her study, Korsko demonstrated that complaints followed a format and a climax-anticlimax trajectory. She observed that "the mounting tension, building as new points are raised and refuted by the interlocutors, eventually reaches a turning point and falls” (p. 7).

Although some interesting studies in the pragmatics of BP have been conducted, the study of refusals by BP speakers is still an open area of 
investigation. The aim of this study is, therefore, to help to better understand how speakers of BP refuse invitation among friends. Following the rationale in Beebe et al. (1990), I analyze the content and order of the pragmatic strategies. I do not focus on the frequency, as Beebe et al. did, because of the low number of participants. This study may be considered the first step toward a better understanding of the speech act of refusals of invitation among friends in Brazilian Portuguese.

\section{Methodology}

\subsection{Participants}

Four native speakers of Brazilian Portuguese (BP) participated in this study (see Table 1). They were born in Brazil and were living in New York City at the time when this study was conducted. All four participants were close friends; their average age was 37.25; their average length of stay in the U.S.A. was 7.25 years. (The real names were replaced by pseudonyms.)

TABLE 1

Participants' background information

\begin{tabular}{lcc}
\hline Participants & Age & Length of stay in the U.S.A. (in years) \\
\hline Marcelo & 32 & 7 \\
Daniel & 50 & 5 \\
Adélia & 35 & 8 \\
Jorge & 32 & 9 \\
\hline
\end{tabular}

\subsection{Procedures}

The data collection took place at the participants' houses in New York City. The data collection occurred as followed: One of the participants, Marcelo (the offerer), invited the other participants to his birthday party. The party was to take place at a day and time when no one would be able to attend. Consequently, refusals were expected. Only Marcelo was aware that the invitation had the purpose of eliciting data, ${ }^{1}$ and the researcher instructed him to act as naturally as possible. 
Marcelo met each participant on different occasions at their houses. The invitation was made by Marcelo at the moment that he felt was most appropriate. The interactions were recorded on a WS-321M digital voice recorder. After the interaction, Marcelo explained to his friends that the invitation was actually part of a research project, told them the reasons of this type of data collection, and asked them for their permission to use the data. All participants gave him their permission and expressed their desire to follow up on the results of the study, which was promptly agreed to by the researcher.

The dialogues were transcribed and analyzed (see Appendices B, C, and $D$ for the complete transcriptions). In each dialogue the refusals were analyzed, focusing on the strategies and semantic formulas applied by the speakers.

\section{Data analysis and discussion}

\subsection{Dialogue I - Daniel (D) and Marcelo (M)}

The first refusal is the most complex and the longest (1minute 43 seconds) of the three analyzed in this paper (see Appendix B for the complete dialogue). I start by analyzing the semantic content of the refusal, followed by the order of semantic formulas.

2. D: Olha, querido, hoje não vou poder ir com vocês porque eu tenho que ir a Perth Amboy.

Look, dear, today I can't go with you because I have to go to Perth Amboy.

In order to express refusal, Daniel gave a considerably long and complex response. In line 2, he started his speech act of refusal 2 by using an Adjunct Olha ('Look') followed by querido ('dear'), which is a common vocative used among good friends (including male friends), close family members, and lovers. The Adjunct 'look' can also work as a vocative. The use of vocative functions as an alert (KOIKE, 1992). The use of 'dear', especially, seems to have two functions: it expresses friendship while, at the same time, it prepares the offerer to accept a refusal. 'Olha' also seems to prepare the offerer for the refusal. Therefore the sequence 'Look, dear' can be considered a prerefusal strategy which has the function of being a softener. 
Next, Daniel said 'today I cannot go with you because I have to go to Perth Amboy.' The Direct Refusal is followed by a Justification, which seems to mitigate the refusal. Daniel started his utterance with 'today'; by fronting the adverb, Daniel produced a semantic effect: he highlighted the day as the main reason for his refusal, possibly implying that he could meet the offerer another day.

3. D: Senão iria com o maior prazer.

Otherwise I would go with great pleasure.

\section{D: Mas eu vou voltar a hora que vocês quiserem.}

But I will come back anytime you want.

Expressing 'empathy' seems to be an important strategy used by Daniel when refusing the invitation. In doing so, Daniel first used a Positive Remark in line 3. His Positive Remark softened the refusal and worked as a politeness strategy. In Takahashi and Beebe (1993)'s analysis of Positive Remarks among Japanese and Americans, the researchers argue that Positive Remarks are distinctive, depending on the speech act. They state that in correction, Americans tend to use Positive Remarks before saying 'but' when they are talking to someone in a lower position, for example, a professor talking to a student (e.g., 'That was a good report, but...'), whereas, in the same context, Japanese used them very rarely. In Takahashi and Beebe’s study, Americans' Positive Remarks are an important preface to disagreement in corrections. In this study, the Positive Remark was a postrefusal strategy. It is a politeness strategy to save the hearer's and the speakers' positive face.

In line 4, Daniel then promised to come back. In Beebe et al (1990)'s taxonomy of refusals, promise of future acceptance is identified as a type of semantic formula used by refusers. Through the use of a Promise, Daniel, once again, expressed empathy and mitigated his refusal.

Daniel initiated his Promise with but. According to Schiffrin (1987), but is used "when the speakers' perceptions clash with their sense of what would constitute a suitable self for presentation to their hearers" (p. 158). In this case, the use of but differentiates two parts of Daniel's response to Marcelo's invitation: the first part was the refusal; the second part minimizes the extent of the refusal. But has a pragmatic effect, since it not only shows that what is about to be said contrasts with what was said before; it also demonstrates the speaker's effort to mitigate his inability to accept the invitation. 
Next, Daniel expanded his Justification by giving a more detailed and personal explanation, which goes from lines 5 to 13 (see Appendix B for the complete Justification):

\section{D: Hoje como esta senhora vem me ver de Miami, que a} filha dela vive na Flórida.

Today this lady comes to see me from Miami, her daughter lives in Florida.

[...]

13. D: Como passa o tempo rápido.

How the time flies!

Daniel talked about the person he had to meet, where and why he would meet her, and other matters. He digressed from the original topic. The focus now was on a person that he had not seen for a long time. Daniel's digression ends in line 13 by saying 'time flies'.

Digression can be considered a textual portion that is not directly linked to the preceding segment or to the following segment; however, it is neither accidental nor a rupture of coherence (ANDRADE, 2001). From the interaction perspective, Digression works as a strategy. In Daniel's speech, Digression is associated with relevance and the importance of Daniel's commitment. It "brings life to the textual game and allows a greater involvement from the interlocutors" (ANDRADE, 2001, p. 127) (my translation).

According to Schiffrin (1987), providing more information than the information requested can be seen as socially cooperative. It can function as remedial work when the speaker does not complain with a request.

The tendency of Brazilians to personalize Justifications was observed by Naiditch (2006). Naiditch defines personalization as a "kind of justification that speakers construct by sharing personal problems or private issues” (p. 137). According to him, PB speakers "personalize their justification without worrying about losing face at all” (p. 237). Daniel's digression works as a Personalized Justification. Therefore, Personalized Justification might be considered a common feature in PB pragmatics and, possibly, a common pragmatic strategy used in refusals among friends.

In line 14, Daniel recovered the original topic when he said: 
14. D: Mas eu vou sim encontrar com vocês se marcar um dia.

But, yes I will meet you if you set up a day.

The use of but works as a marker to announce the reintroduction of the original topic. It is also "marks an upcoming unit as a contrasting action" (SCHIFFRIN, 1987, p. 152). It can also be seen as Daniel's effort to return to a prior concern of saving face and being socially cooperative.

Yes, in the middle of the sentence, functions as an intensifier, an upgrader. Upgraders "are elements whose function is to increase the impact" (BLUMKULKA, 1989, p. 285). These modifiers intensify certain elements of the proposition of the utterance. In the next utterance, Daniel continued using upgraders.

15. D: Talvez quinta-feira inclusive aí vou com você.

Maybe including Thursday, then I will go with you.

Daniel ended his refusal in line 15 by offering an Alternative. The use of the hedge talvez ('maybe') functions as a downgrader; that is, it "mitigate[s] the respective illocutionary force" of his offer to go on Thursday (BARRON, 2003, p. 140). The use of a hedge before the Alternative weakens the assertiveness of the utterance. At the same time, Daniel used two upgraders: 'including' and 'then,' which reinforced and intensified the idea expressed in the utterance. The use of downgraders and upgraders in the same utterance produces an interesting effect: it shows the speaker's assertiveness, yet it is not imposing.

Regarding the order of semantic formulas, Daniel produces the following sequence in only one turn: ADJUNCT + VOCATIVE (SOFTENERS) $\rightarrow$ DIRECT REFUSAL $\rightarrow$ JUSTIFICATION $\rightarrow$ POSITIVE REMARK $\rightarrow$ PROMISE $\rightarrow$ PERSONALIZED JUSTIFICATION $\rightarrow$ DIGRESSION $\rightarrow$ RECOVERY OF THE ORIGINAL TOPIC $\rightarrow$ ALTERNATIVE.

\subsection{Dialogue II - Adélia (A) and Marcelo (M)}

This is the shortest dialogue (26 seconds) and it is the only one in which neither a refusal nor an acceptance of invitation occurred (see Appendix $C$ for the complete dialogue). Adélia's response to the invitation was 'I don't know' (line 2). According to Gass and Houck (1999), the hearer can accept or not accept an invitation. A nonaccept can be expressed as a refusal, an alternative, or a 
postponement. 'I don't know' is therefore a way to postpone a decision, as long as it is sincere. If it is not sincere, it can be considered a way to refuse by avoidance. "White lies" are actually a pragmatic strategy that some speakers might use when unable to give a positive response. Japanese speakers, for example, tend to favor "white lies" as a way to express refusal (UEDA, 1972). In order to verify if Adélia was being sincere, contact was made with her and she confirmed that her response was sincere. Therefore, in Adélia's response, postponement is considered a nonaccept (but not a refusal).

1. M: Adélia, você quer jantar comigo na quinta-feira pra comemorar meu aniversário por volta das quatro horas?

Adélia, do you want to have dinner with me to celebrate my birthday on Thursday around four o'clock?

2. A: Eu não sei.

I don't know.

3. A: Tenho que ver lá no salão.

I have to see there at the salon.

4. A: Porque se não tiver ninguém pra me substituir, eu não posso ir.

Because if there is nobody to replace me, I can't go.

After the Postponement, in line 4, Adélia justified the response. The Justification was followed by a short Personalized Justification. In Adélia's response, 'I' was the perspective of the speaker's view point. ${ }^{2}$ Choosing a performance of I-perspective, Adélia explicitly named herself as the agent of the action (Naiditch, 2006). The choice of the I-perspective is marked by the use of the first person singular pronoun (I), and by the personal and tense markers in the verbs (e.g., tenho 'I have'). On the next turn, Adélia shifted the perspective.

5. M: Não tem como mudar?

There is not way to change it?

6. A: Num sei.

I don't know. 


\section{A: Tem que ver lá.}

Have to see there.

\section{A: Primeiro eu vou ver.}

First I will see.

Adélia started her second nonaccept in line 6 in the same way that she started the first one, with some subtle changes. This time, 'I don't know' is more informal, used only in colloquial conversation: the personal pronoun 'I' is dropped and the negative 'no' becomes Num.

In line 7, Adélia shifted the perspective. The verb tem (have) marks the Impersonal Perspective. In this perspective, the speaker avoids mention of the agent(s) (NAIDITCH, 2006). The Impersonal Perspective is marked by conjugating the verb in the third person singular in BP. According to Naiditch, Shifting Perspective occurs "as a result of negotiation" (p. 154). Shifting Perspective, in this case from I-Perspective to Impersonal Perspective, "frees the hearer from the imposing of a more personal approach" (p. 162) and it can be considered a politeness strategy used by BP.

Line 8, the next utterance, is a Repetition of the Justification; Shifting Perspective occurred again, from Impersonal to I-Perspective. In Beebe et al. (1990)'s classification of semantic formulas, Repetition is considered a strategy for avoidance. In this study, Repetition seems to reinforce the message, to reassure it.

9. M: Tá bom então.

That's fine then.

10. A: Tá? $O k$ ?

'That's fine then' (line 9) is a closing formula in BP. Adélia, however, seemed not to see it as a closure. Tá, in line 10, is the short form of está bem ('that's fine'), which can be used as a form of agreement, or as a Tag Question with final rising intonation. In this case, the use of Tá did not aim to request agreement, since Adélia already knew that Marcelo had accepted her Justification. I call the information added after the closure of the speech act as Post-closure Continuance. The Tag Question Tá seems to be another pragmatic strategy among friends. According to Koike (1992), BP tags can function as softeners among peer registers in order to "build solidarity with the hearer" 
(p. 46). The use of Tá by Adélia softens the refusal (or the postponement, in this case), at the same time that it asks for understanding on the hearer's part.

Adélia's responses had the following sequence of pragmatic strategies:

a) First turn: POSTPONEMENT $\rightarrow$ JUSTIFICATION (I-Perspective) $\rightarrow$ PERSONALIZED JUSTIFICATION.

b) Second turn: POSTPONEMENT (Repetition) $\rightarrow$ JUSTIFICATION (Impersonal Perspective) $\rightarrow$ JUSTIFICATION (Repetition - I-Perspective).

c) Third turn: POST-CLOSURE CONTINUANCE (Tag question).

\subsection{Dialogue III - Jorge (J) and Marcelo (M)}

In line 4, Jorge started his refusal by offering the hearer a Justification (see Appendix D for the complete dialogue).

1. M: Jorge, você gostaria de sair pra comemorar meu aniversário na quinta-feira às quatro horas da tarde?

Jorge, would you like to go out to celebrate my birthday on Thursday at four o'clock in the afternoon?

2. M: É um almoço.

It is a lunch.

3. M: Vai ser o pessoal lá do trabalho mas...

With the people there from work but... (Brief pause.)

4. J: Quatro horas da tarde eu tô enTRANdo no trabalho.

Four o'clock in the afternoon I'm STARTing work.

Jorge expressed refusal through Justification. Although Jorge did not state that he could not go, the hearer understood the implicature, since implicatures are based on the cooperative principle (GRICE, 1975). It is also interesting to note that Jorge rose the intonation when he pronounced the tonic syllable of the word entrando (starting) as a way to emphasize the Justification. Intonation is considered a type of upgrader. Koike (1992) states that the use of intonation by BP speakers can be an important component in the realization of speech acts. Although it is not the focus of this paper to analyze the intonation, it seems to be 
a relevant element to be considered when analyzing pragmatic strategies by BP speakers. It should not be overlooked.

5. M: E não tem... Você vai todas a quintas-feiras... Não tem como...

And there is no way... You go every Thursdays... There is no way...

6. J: Olha, mais cedo do que isso...

Look, earlier than this...

7. J: Eu posso sair mais tarde.

I can go later.

8. J: Mais cedo...

Earlier...

In line 6, Jorge started his second refusal by using an Adjunct ('look'), which also functions as a vocative. It is interesting to note that Jorge did not finish his sentences. However, the hearer seemed not to have problems in understanding them (e.g., the hearer did not ask for further explanation). Speakers may be familiar enough with such situations that they just fill in the sentence. It might be possible that the Incomplete Refusals were accompanied by gestures (e.g., facial expressions), which would index negation. However, this could not be confirmed since the researcher possessed the recorded voice, not the images.

After the first Incomplete Refusal, Jorge offered an Alternative in line 7. Another Incomplete Refusal (a Repetition) came next in line 8. By using complete sentences only when he offered an Alternative, Jorge focused on the Alternative, not on the refusal itself.

The use of Incomplete Refusals was also observed among Japanese (SHIMURA, 1995). Incomplete Refusals are used as a politeness strategy among Japanese, and it seems to be used more often when the hearer is of high status. This is not the case in this study, since all participants were intimates. Incomplete Refusals can be considered a pragmatic strategy in refusals in BP. By using this strategy, Jorge avoided explicit negation and favored certain ambiguity. 


\section{M: Ah, tá bom então.}

Ah, that's fine then.

10. J: É que o cara que me substitui e que às vezes eu subtituo ele, só pode ir depois das sete.

Because the guy that substitutes for me and that sometimes I substitute for can only go after seven.

\section{M: Tá ok.}

That's ok.

As happened in Adélia's response, Jorge did not consider Marcelo's utterance, expressed in line 9, as the closure of the speech act. Jorge seemed to feel that he had to explain a little bit more, even after Marcelo signaled that he was fine with his response. In line 10, he applied the Post-closure Continuance strategy, expanding his explanation with personal information. Once again, Personal Justification seems to be an important strategy among Brazilian friends: it allows the hearer to understand the reason and it shows him or her that the speaker is being considered.

As mentioned before, BP speakers might favor Personalized Justifications. In his study, Naiditch (2006) observed that BP speakers tended to avoid vague explanations more than American English speakers. It might be that Justification by itself is not enough to save the speakers' positive face. Volunteering more information appears to be relevant in order to save face in refusals. It might also be a way for speakers to left themselves off the hook, therefore, freeing themselves from any blame.

Jorge refused the invitation in three turns, following the order below:

a) First turn: JUSTIFICATION.

b) Second turn: INCOMPLETE REFUSAL $\rightarrow$ ALTERNATIVE $\rightarrow$ INCOMPLETE REFUSAL (Repetition).

c) Third turn: POST-CLOSURE CONTINUANCE (Personalized Justification). 


\subsection{Further consideration}

Semantic formulas, such as obrigado ('thank you') and Me desculpe ('I'm sorry'), are conventional markers of politeness in BP. However, none of the participants used those markers in their interaction when refusing an invitation from a friend. As mentioned in the literature review, the lack of politeness markers does not translate to rudeness or impoliteness, and it is a common feature in the BP interaction. Brazilians have other resources to express politeness, such as prosodic and paralinguistic features (NAIDITCH, 2006). Naiditch cited Bechara (1991), who argues that the decline in the use of linguistic politeness (e.g., por favor 'please') is related to social movements in Brazil that promote social justice and focus on reducing social distances. Naiditch concludes that the "relative lack of linguistic politeness in Brazilian Portuguese, therefore, reflects this trend in Brazilian culture to treat people equally, regardless of their background" (p. 122). Although Naiditch presents us with an interesting explanation for the lack of conventional markers of politeness in BP, more research should be done in order to investigate this phenomenon more thoroughly. We can conclude that, not only the presence, but also the absence of certain conventional semantic markers of politeness seem to characterize the speech acts of refusals in BP.

\section{Conclusion}

In this study, the content and order of semantic and pragmatic strategies applied by BP speakers in the speech acts of refusals of an invitation among friends were analyzed. The three participants showed that the order of refusals can be an elaborated process (see Figure 1).

As mentioned before, this study followed the rationale in Beebe et al.'s (1990). Although similarities were found between semantic formulas described in Beebe et al.'s study and this one (e.g., Alternatives and Promises), BP speakers used other formulas not mentioned in Beebe et al.'s (e.g., Digression and Incomplete Refusals) (see Appendix A for a complete list of semantic formulas analyzed in this study). The differences might be related to the methodologies applied by the researchers, since Beebe at al. used DCT, whereas this research collected natural data. Other semantic formulas, such as Repetition, were found in both studies; however, in Beebe et al.'s, Repetition is a way to 
express avoidance, whereas, in this study, it reinforces the illocutionary force. In addition, the lack of conventional politeness markers (e.g., 'thank you,' 'I'm sorry') was also a distinctive feature observed among BP speakers, as well as the use of Post-closure Continuance, the addition of more information following the offerer's closure.

This study has limitations, the most relevant being the low number of participants. Other studies might consider a greater number of speakers, which would allow the researcher to investigate other aspects of the speech act of refusals (e.g., the frequency of semantic formulas).

In addition to the study of speech act production, analysis of speech act perception can contribute to a better understanding of refusals. In this study, it seemed that a Personalized Justification was expected from the hearer. A study focusing on perception might confirm or refute this impression.

Finally, the participants who refused the invitation to a friend's birthday party offered an Alternative (e.g., another day or time). In other cultures, an Alternative might not be appropriate. Some Americans told me informally that they would not suggest an Alternative when refusing an invitation to a friend's birthday party. Some added that 'it would be a weird thing to do.' On the other hand, we might consider the possibility that the participants were applying the Alternative strategy as a way to get together with the offerer on a one-on-one basis, not a suggestion to him to re-schedule his birthday party. Notwithstanding this, cross-linguistic differences can be an interesting topic for future investigation.

As Beebe et al. (1990) said, "refusals are a major cross-cultural sticking point for many nonnative speakers" (p. 56). The study of the speech act of refusals among learners of Portuguese as a second language can help researchers to better understand the learners' interlanguage pragmatics. The study of refusals among BP speakers can also help instructors to become aware of the pragmatic strategies that native speakers employ in their everyday lives; helping them to be better able to guide learners of Portuguese to advance confidently toward the target language. 
Overview of refusal trajectories produced by the three participants

(Following Gass and Houck (1999)'s overview representation.)

\section{Initial Act}

(Would you like to come to my birthday party?)

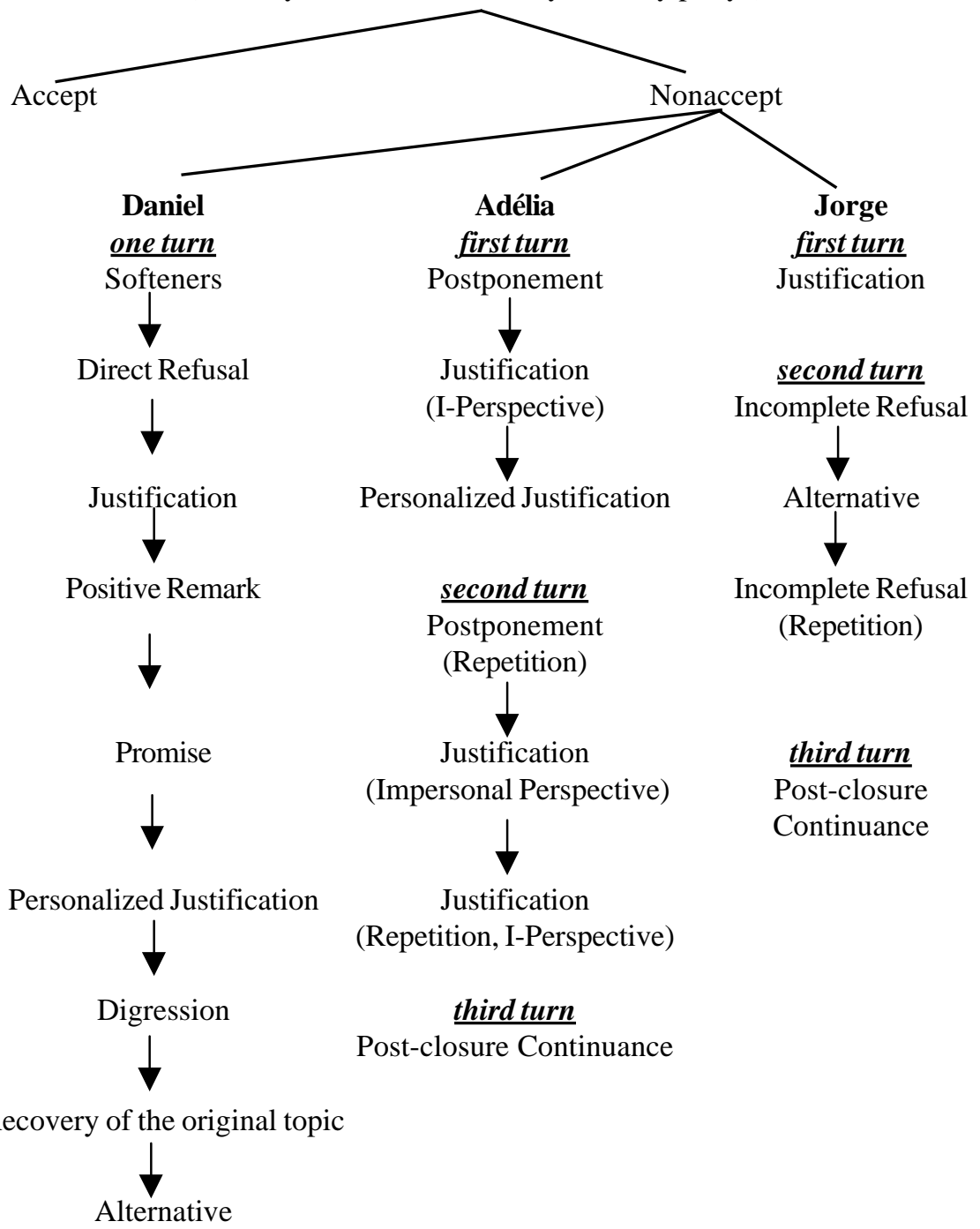

FIGURE1 


\section{Notes}

${ }^{1}$ Following the ethical standards of the AERA (American Educational Research Association) (AERA, 2009), researchers might use deception only if it is clearly necessary, and it should be minimized. After the study, participants should become aware of the deception and its reasons. In this study, deception was necessary, since the aim was to obtain natural speech. However, the researcher also took into consideration the extent of the deception and the magnitude of its impact on the participants.

${ }^{2}$ In Portuguese, the first person subject pronouns are not required in the sentence. Brazilian Portuguese is considered a partially pro-drop system (Kato, 2000). The present of the subject pronouns may be marked.

\section{References}

AMERICAN EDUCATIONAL RESEARCH ASSOCIATION. Disponível em: < http:/ /www.aera.net/>. Acesso em: 20 abr. 2009.

ANDRADE, M. L. C. V. D. A digressão como estratégia discursiva na produção de textos orais e escritos. In: PRETI, D. (Ed.). Fala e escrita em questão. São Paulo: Humanitas FFLCH/USP, 2001. p. 99-128.

BARRON, A. Acquisition in interlanguage pragmatics. Learning how to do things with words in a study abroad context. Philadelphia: John Benjamins, 2003.

BECHARA, E. A polidez e as línguas. D. O. Leitura, v. 9, p. 108, 1991.

BEEBE, L. M.; TAKAHASHI, T.; ULISS-WELTZ, R. Pragmatic transfer in ESL refusals. In: SCARCELLA, R. C.; ANDERSEN, E. S.; KRASHEN, S. D. (Ed.). Developing communicative competence in a second language. New York: Newbury House Publishers, 1990. p. 55-73.

BLUM-KULKA, S. Playing it safe: The role of conventionality in indirectness. In: BLUM-KULKA, S.; HOUSE, J.; KASPER, G. (Ed.). Cross-cultural pragmatics: Requests and apologies. Norwood, NJ: Ablex, 1989. p. 37-70.

BROWN, P.; LEVINSON, S. Universals in language use: Politeness phenomena. In: GOODY, E. N. (Ed.). Questions and politeness: Strategies in social interaction. New York: Cambridge University, 1978. p. 56-289.

FÉLIX-BRASDEFER, J. C. Interlanguage refusals: Linguistic politeness and length of residence in the target community. Language learning, v. 54, n. 4, p. 587-653, 2004.

FÉLIX-BRADESFER, J. C. Perceptions of refusals to invitations: Exploring the minds of foreign language learners. Language awareness, v. 17, n. 3, p. 195-211, 2008. 
GASS, S. M.; HOUCK, N. Interlanguage refusals. A cross-cultural study of Japanese-English. New York: Mouton de Gruyter, 1999.

GRICE, H. P. Logic and conversation. In: COLE, P.; MORGAN, J. (Ed.). Syntax and semantics. New York: Academic Press, 1975. v. 3, p. 41-58.

GUMPERZ, J. The conversational analysis of interethnic communication. In: ROSS, E. L. (Ed.). Interethnic communication. Athens, GA: University of Georgia Press, 1978. p. 13-31.

KATO, M. A.; NEGRÃO, E. V. (Ed.). Brazilian Portuguese and the null subject Parameter. Frankfurt-Madrid: Vervuert-IberoamericaCOLna, 2000.

KOIKE, D. A. Language and social relationship in Brazilian Portuguese. The pragmatics of politeness. Austin, Texas: University of Texas Press, 1992.

KORSKO, P. The narrative shape of two-party complaints in Portuguese: A discourse analytic study. Dissertation Abstracts International, v. 64, n. 12, p. 4443, 2004. UMI No. 3117842.

NAIDITCH, F. The pragmatics of permission: a study of Brazilian ESL learners. Dissertation Abstracts International, v. 67, n. 5, 2006, UMI No. 3215491.

Projeto NURC/SP - Projeto de Estudo da Norma Linguística Urbana Culta de São Paulo. Disponível em: <http://www.fflch.usp.br/dlcv/nurc/index.html>. Acesso em: 15 abr. 2009.

ROSE, K. R.; KASPER, G. Pragmatics in language teaching. Cambridge: Cambridge University Press, 2001.

SCHIFFRIN, D. Discourse Markers. Cambridge and New York: Cambridge University Press, 1987.

SCHWENTER, S. A. The pragmatics of negation in Brazilian Portuguese. Lingua, v. 115, p. 1427-1456, 2005.

SHIMURA, A. Frequency, function, and structure of omissions as politeness expressions in the speech act of refusal. Language, culture, communication, v. 15, p. 41-62, 1995.

TAKAHASHI, T.; BEEBE, L. Cross-linguistic influence in the speech act of correction. In: KASPER, G.; BLUM-KULKA, S. (Ed.). Interlanguage Pragmatics. Oxford: Oxford University Press, 1993. p. 138-158.

UEDA, K. Sixteen ways to avoid saying 'no' in Japan. In: CONDON, J.; SAITO, M. (Ed.). Intercultural encounters with Japan: Communication-contact and conflict. Dordrecht: Kluwer, 1972. p. 185-192. 


\section{APPENDIX A}

Summary of the semantic formulas and phrases employed in refusals by BP speakers in this research

A - Classification of semantic formulas:

1. Direct Refusal (“I can’t go...”)

2. Justification ("I cant' go with you because..."

3. Personalized Justification (“Today this lady comes to see me...”)

4. Positive remark (“Otherwise, I will go with great pleasure.”)

5. Promise ("But I will come back anytime you want.”)

6. Digression

7. Alternative ("I can go out later.")

8. Postponement (“I don’t know.”)

9. Repetition

10. Tag Question (“Ok?”)

11. Intonation

12. Incomplete Refusal (“Earlier...”)

13. Shifting Perspective

14. Post-closure Continuance

B - Categorization of phrases employed in refusals:

1. Adjuncts ("look")

2. Vocatives ("dear")

3. Upgraders ("inclusive”)

4. Hedges ("maybe")

5. Lack of conventional politeness markers (“I’m sorry.”)

C - Phrases avoided or not employed in refusals:

Lack of conventional politeness markers (“I'm sorry.”) 


\section{APPENDIX B}

Dialogue between Daniel (D) and Marcelo (M):

1. M: Você gostaria de sair para jantar na quinta-feira à noite no meu aniversário?

Would you like to go out for dinner for my birthday this Thursday at night?

2. D: Olha, querido, hoje não vou poder ir com vocês porque eu tenho que ir a Perth Amboy.

Look, dear, today I can’t go with you because I have to go to Perth Amboy.

3. D: Senão iria com o maior prazer.

Otherwise I would go with great pleasure.

4. D: Mas eu vou voltar a hora que vocês quiserem.

But I will come back anytime you want.

5. D: Hoje como esta senhora vem me ver de Miami, que a filha dela vive na Flórida.

Today this lady comes to see me from Miami, her daughter lives in Florida.

6. D: Então, elas estão no culto da igreja. Then, they are part of the church service.

7. D: Então daqui quinze minutos, elas tão vindo aqui pra me pegar pra ir a Perth Amboy.

Then, in fifteen minutes, they are coming here to pick me up to go to Perth Amboy.

8. D: Eu pretendo ver a menina dela. I intend to see her daughter.

9. D: Quando vi a menina dela, tava com 10 anos. When I saw her daughter, she was 10 years old.

10. D: Agora faz 8. It has been 8 years.

11. D: Ela tá com 18 anos. She is now 18 years old.

12. D: A menina dela casou tão nova, e já tá aqui já. Her daughter got married so young, and she is already here.

13. D: Como passa o tempo rápido. How the time flies!

14. D: Mas eu vou sim encontrar com vocês se marcar um dia. But, yes I will meet you if you set up a day.

15. D: Talvez quinta-feira inclusive aí vou com você. Maybe including Thursday,then I will go with you.

15. M: Ok. 


\section{APPENDIX C}

Dialogue between Adélia (A) and Marcelo (M):

1. M: Adélia, você quer jantar comigo na quinta-feira pra comemorar meu aniversário por volta das quatro horas?

Adélia, do you want to have dinner with me to celebrate my birthday on Thursday around four o'clock?

2. A: Eu não sei.

I don't know.

3. A: Tenho que ver lá no salão.

I have to see there at the salon.

4. A: Porque se não tiver ninguém pra me substituir, eu não posso ir. Because if there is nobody to replace me, I can't go.

5. M: Não tem como mudar?

There is not way to change it?

6. A: Num sei.

I don't know.

7. A: Tem que ver lá.

Have to see there.

1. A: Primeiro eu vou ver.

First I will see.

2. M: Tábom então.

That is fine then.

3. A: Tá? Ok? 


\section{APPENDIX D}

Dialogue between Jorge (J) and Marcelo (M) :

1. M: Jorge, você gostaria de sair pra comemorar meu aniversário na quintafeira às quatro horas da tarde?

Jorge, would you like to go out to celebrate my birthday on Thursday at four o'clock in the afternoon?

2. M: É um almoço.

It is a lunch.

3. M: Vai ser o pessoal lá do trabalho mas... With the people there from work but... (Brief pause.)

4. J: Quatro horas da tarde eu tô enTRANdo no trabalho. Four o'clock in the afternoon I'm STARTing work.

5. M: E não tem... Você vai todas a quintas-feiras... Não tem como... And there is no way... You go every Thursdays... There is no way...

6. J: Olha, mais cedo do que isso... Look, earlier than this...

7. J: Eu posso sair mais tarde. I can go later.

8. J: Mais cedo... Earlier...

9. M: Ah, tá bom então. Ah, that's fine then.

10. J: É que o cara que me substitui e que às vezes eu subtituo ele, só pode ir depois das sete.

Because the guy that substitutes for me and that sometimes I substitute for can only go after seven.

11. M: Tá ok.

That's ok. 